
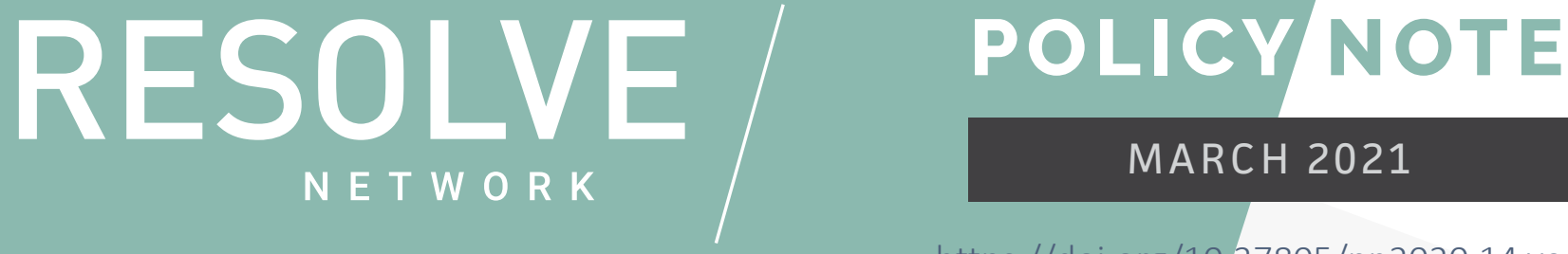

https://doi.org/10,37805/pn2020.14.vedr

\title{
STIGMA, SHAME, AND FEAR: NAVIGATING OBSTACLES TO PEACE IN MINDANAO
}

\author{
HARORO J. INGRAM
}

VIOLENT EXTREMIST

DISENGAGEMENT AND RECONCILIATION

\section{${ }^{66}$ Disengagement and reintegration activities conducted as part of a formal peace process must reduce barriers to and maximize incentives for participation."}

\section{FAST FACTS}

$\rightarrow$ Stigma, shame, and fear may act as obstacles but also opportunities that need to be understood and appropriately harnessed in disengagement and reintegration initia-

tives.

$\rightarrow$ For many former combatants, decommissioning is a time of acute uncertainty. Successful disengagement and reintegration require psychological, social, and practical (e.g. livelihood, security) support efforts to alleviate fears of what an "unarmed" future may mean.

$\rightarrow$ Pathway and vulnerability mapping is programmatically important because it demands practitioners to engage in assessments of individual, social, and structural factors at play in their local communities.

\section{Context}

After decades of cyclical peace agreement failures and war in Mindanao, the establishment of the Bangsamoro Autonomous Region of Muslim Mindanao (BARMM) in early 2019 brought the best hope for sustainable peace and stability in living memory. ${ }^{1}$ Home to one of the world's longest internal conflicts, ${ }^{2}$ Mindanao now has a path towards peace with an appointed interim

1 Sofia Tomacruz, "Now that Bangsamoro law is ratified, what comes next?," Rappler, January 31, 2019, https://www.rappler.com/ newsbreak/iq/things-to-know-transition-bangsamoro-organic-law; Zachary Abuza and Luke Lischin, "The challenges facing the Phlippines' Bangsamoro Autonomous Region at one year," United States Institute of Peace, Special Report, June 10, 2020, https://www. usip.org/index.php/publications/2020/06/challenges-facing-philippines-bangsamoro-autonomous-region-one-year.

2 Steven Rood, The Philippines (Oxford University Press, New York, 2019): 101-108; Salvatore Schiavo-Campo and Mary Judd, "The Mindanao conflict in the Philippines: Roots, costs, and potential peace dividend," World Bank, Social Development Paper 
Bangsamoro government, the Bangsamoro Transition Authority (BTA), responsible for taking the region through the political/legal and normalization tracks of the peace process and towards its first elections. ${ }^{3}$ The BTA has made admirable progress in a short time and amidst significant challenges. But the problems within the BARMM and Mindanao more broadly are immense. If crippling poverty, undereducation, high unemployment, the destabilizing effects of incessant clan conflicts (rido), long-running insurgencies, and seasonal natural disasters were not enough, the island's inhabitants are now grappling with the coronavirus pandemic.

Having travelled regularly to Mindanao since late 2017, I have interviewed and surveyed hundreds of people, particularly in Lanao del Sur and Maguindanao. A trifecta of stigma, shame, and fear is regularly identified as levers exploited by peace spoilers to not only recruit and mobilize from local communities but obstruct disengagement and reintegration efforts. ${ }^{4}$ The widespread and intergenerational experiences of trauma across Mindanao hangs like an invisible pall over almost every aspect of life. The dynamics of stigma, shame, and fear in Mindanao tend to be multidimensional in that they may emerge from a range of sources and multidirectional in their effect, as different sources of stigma, shame, and fear can push and pull individuals and groups in different ways. Stigma, shame, and fear may act as obstacles but also opportunities that need to be understood and appropriately harnessed in disengagement and reintegration initiatives. ${ }^{5}$ This policy note offers a framework of recommendations that are largely grounded in peacebuilding approaches. ${ }^{6}$

Overall, this policy note argues that the design and implementation of disengagement and reintegration efforts should be shaped around three core pillars.

$\rightarrow$ First, successful disengagement and reintegration is often reliant on outcompeting malign actors to persuade individuals towards certain behaviors over others, commitment to certain groups over others, and, potentially, with time, enable the deeper attitudinal shifts that can help to make disengagement and reintegration more resilient and sustainable.

series, Conflict Prevention \& Reconstruction, 2005, http://documents.worldbank.org/curated/en/701961468776746799/ pdf/31822.pdf.

3 Mindanao People's Caucus, Rapid midterm review of the Bangsamoro transition period, October 2020, 47-54. https://iag.org. ph/images/pdf/Part I Final Report 10-26-2020.pdf; Georgi Engelbrecht, "Covid-19 shakes South Philippine peace deal," Asia Times, December 4, 2020, https://asiatimes.com/2020/12/covid-19-shakes-south-philippine-peace-deal/.

4 For broader studies of disengagement and reintegration research and practice, see: Mary Beth Altier, Christian N. Thoroughgood, and John G. Horgan, "Turning away from terrorism: Lessons from psychology, sociology, and criminology," Journal of Peace Research 51, no. 5 (2014): 647-661; Mary Beth Altier, Emma Leonard Boyle, Neil D. Shortland, and John G. Horgan, "Why they leave: An analysis of terrorist disengagement events from eighty-seven autobiographical accounts," Security Studies 26, no. 2 (2017): 305-332.

5 While this policy note focuses on the importance of understanding the role of stigma, shame, and fear as potential obstacles and opportunities to shape disengagement and reintegration initiatives, this is not to imply that these are the only psychosocial considerations for scholars and practitioners. It is especially important to emphasize that practitioners must carefully and methodically assess every case on its merits to make evidence-based programmatic decisions.

6 For more on the applicability of peacebuilding approaches to disengagement, reintegration and reconciliation programs, see: Chris Bosley, "Violent extremist disengagement and reconciliation: A peacebuilding approach, United States Institute of Peace, 2020, https://www.usip.org/publications/2020/07/violent-extremist-disengagement-and-reconciliation-peacebuildingapproach; Leanne Erdberg Steadman, “Disengagement and Reconciliation in Conflict-Affected Settings," United States Institute of Peace, 2020, https://www.usip.org/publications/2020/08/disengagement-and-reconciliation-conflict-affected-settings. 
$\rightarrow$ Second, these persuasion dynamics are best understood by thinking of stigma, shame, and fear as one side of a duality of psychosocial and strategic levers, on the other side of which are honor, redemption, and empowerment. For instance, stigma, shame, and fear are often used as levers by recruiters and other mobilizers, typically by juxtaposing those feelings (or potential feelings) with opportunities to achieve honor, redemption, and empowerment. At the heart of disengagement and reintegration efforts is the competition over who can better harness these dynamics for persuasion.

$\rightarrow$ Third, how individuals provide support to violent actors varies along a behavioral and attitudinal spectrum. ${ }^{7}$ These variations in support have implications for the role of shame, stigma, and fear as drivers towards or away from participation in disengagement and reintegration programs and on the types of activities-from livelihood support to engagement in public reconciliation programs-necessary to rendering the pathways back to violence inviable.

The central challenge for government and civil society actors is to understand and harness these dynamics in disengagement and reintegration programs, guided by core principles but always nuanced on a case-by-case basis. Mindanao offers a fascinating case study into the necessary differences in design and implementation of the disengagement and reintegration activities between those within the legal and programmatic frameworks of a formal peace process versus those outside of it.

\section{Relevance to policy \& practice}

This policy note applies the American Psychological Association's definitions of stigma, ${ }^{8}$ shame, ${ }^{9}$ fear, ${ }^{10}$ and trauma. ${ }^{11}$ These powerful psychosocial factors profoundly influence human behavior and contribute to the type of acute stresses that can adversely impact cognitive function, impede decision-making processes, and increase susceptibilities to cognitive biases..$^{12}$ Moreover, stigma,

7 For more on distinguishing between behavioral and attitudinal support and its implications, see: James Khalil, "Insurgentpopulace relations in Nepal: An analysis of attitudinal and behavioural support," Small War and Insurgencies 23, no. 2 (2012): 221-244.

8 "Stigma: $n$. the negative social attitude attached to a characteristic of an individual that may be regarded as a mental, physical, or social deficiency. A stigma implies social disapproval and can lead unfairly to discrimination against and exclusion of the individual." APA Dictionary of Psychology, https://dictionary.apa.org/stigma.

9 "Shame: $n$. a highly unpleasant self-conscious emotion arising from the sense of there being something dishonorable, immodest, or indecorous in one's own conduct or circumstances. It is typically characterized by withdrawal from social intercoursefor example, by hiding or distracting the attention of another from one's shameful action-which can have a profound effect on psychological adjustment and interpersonal relationships. Shame may motivate not only avoidant behavior but also defensive, retaliative anger." APA Dictionary of Psychology, https://dictionary.apa.org/shame.

10 "Fear: $n$. a basic, intense emotion aroused by the detection of imminent threat, involving an immediate alarm reaction that mobilizes the organism by triggering a set of physiological changes." APA Dictionary of Psychology, https://dictionary.apa.org/ fear.

11 "Trauma: $n$. any disturbing experience that results in significant fear, helplessness, dissociation, confusion, or other disruptive feelings intense enough to have a long-lasting negative effect on a person's attitudes, behavior, and other aspects of functioning. Traumatic events include those caused by human behavior (e.g., rape, war, industrial accidents) as well as by nature (e.g., earthquakes) and often challenge an individual's view of the world as a just, safe, and predictable place." APA Dictionary of Psychology, https://dictionary.apa.org/trauma.

12 Rongjun Yu, "Stress potentiates decision biases: A stress induced deliberation-to-intuition (SIDI) model," Neurobiology of Stress 3 (2016): 83-95; World Bank Group, “Mind, Society, and Behavior," World Development Report 2015: 27. 
shame, and fear may emerge in a compounding cycle in which, for instance, experiences of being stigmatized ${ }^{13}$ can cause and/or intensify feelings of fear and shame. This dynamic can dislocate the individual from the broader community and cause profound anxieties and uncertainties, especially regarding self-identity. ${ }^{14}$

Perceptions of crises inevitably create a need in the individual, and the broader group when experienced collectively, to solve those problems. At the heart of this crisis-solution duality are powerful psychosocial forces that may increase vulnerabilities to being perpetrators and victims of violence, including violent extremism. ${ }^{15}$ For example, the linkage method of propaganda analysis examines how violent extremist messaging harnesses these dynamics via narratives that blame out-group identities for crises and endorse a narrowly defined in-group as the only means to achieving solutions. ${ }^{16}$ Violent extremists will exploit stigma, shame, and fear to increase perceptions of crisis on the one hand, while offering solutions and a path to achieve honor, redemption, and empowerment, on the other. For those responsible for disengagement and reintegration efforts in Mindanao, understanding and harnessing these psychosocial dynamics will be crucial.

\section{Challenges past and future}

Of the challenges facing the BARMM government, one of the most pressing is managing expectations in the population for what the peace dividend will deliver. ${ }^{17}$ If hopes are not met by

13 Major and O'Brien argue that there are "four mechanisms by which stigma affects the stigmatized: (a) negative treatment and direct discrimination, (b) expectancy confirmation processes, (c) automatic stereotype activation, and (d) identity threat processes." For more, see: Brenda Major and Laurie T. O’Brien, "The Social Psychology of Stigma," Annual Review of Psychology 56 (February 2005): 396.

14 Helen Block Lewis, 1987, Shame: The "sleeper" in psychopathology (Hillsdale: Erlbaum, 1987): 15; Brene Brown, "Shame resilience theory: A grounded theory study on women and shame," Families in Society 87 (2006): 45; Shlomo Hareli and Brian Parkinson, "What's social about social emotions?," Journal for the Theory of Social Behaviour 38, no. 2 (2008): 131-156.

15 JM Berger, Extremism (Cambridge: MIT Press, 2018); Bertjan Doosje, Annemarie Loseman, and Kees van den Bos, "Determinants of Radicalization of Islamic Youth in the Netherlands: Personal Uncertainty, Perceived Injustice, and Perceived Group Threat," Journal of Social Issues 69, no. 3 (2013): 586-604; Michael A. Hogg and Janice Adelman, "Uncertainty-Identity Theory: Extreme Groups, Radical Behavior, and Authoritarian Leadership," Journal of Social Issues 69, no. 3 (2013): 436454; Michael A. Hogg, Arie Kruglanski, and Kees van den Bos, "Uncertainty and the Roots of Extremism," Journal of Social Issues 69, no. 3 (2013): 407-418, https://doi.org/10.1111/josi.12021; Haroro J. Ingram, Deciphering the Siren Call of Militant Islamist Propaganda (International Centre for Counter-Terrorism - The Hague, September 2016), https://icct.nl/wp-content/ uploads/2016/09/ICCT-Ingram-Deciphering-the-Siren-Call-of-Militant-Islamist-Propaganda-September2016.pdf; Kiriloi M. Ingram, IS's Appeal to Western Women: Policy Implications (International Centre for Counter-Terrorism - The Hague, October 2017), https://www.jstor.org/stable/resrep17481?seq=1\#metadata info tab contents.

16 JM Berger, Extremism (Cambridge: MIT Press, 2018); Alastair Reed and Jennifer Dowling, "The role of historical narratives in extremist propaganda," Defence Strategic Communications, Volume 4 (Spring 2018): 79-104, https://www.stratcomcoe.org/ alastair-reed-jennifer-dowling-role-historical-narratives-extremist-propaganda; Joe Whittaker and Lilah Elsayed, "Linkages as a lens: An exploration of strategic communications in P/CVE," Journal of Deradicalization 20 (2019), https://journals.sfu.ca/ jd/index.php/jd/article/view/243; Haroro J. Ingram, "The Strategic Logic of Islamic State's Full-spectrum Propaganda," in ISIS Propaganda: A Full-Spectrum Extremist Message, eds. Stephane J. Baele, Katharine A. Boyd, and Travis G. Coan (New York: Oxford University Press, 2020): 20-49. https://doi.org/10.1093/oso/9780190932459.003.0002.

17 The Mindanao People's Caucus conducted twenty-one focus group discussions (232 participants) from across the BARMM revealing high expectations for what peace will deliver to the region. For more, see: Mindanao People's Caucus, Rapid midterm review of the Bangsamoro transition period, October 2020, 47-54. https://iag.org.ph/images/pdf/Part I Final 
reality, a variety of peace spoilers - from communist insurgents and violent extremists ${ }^{18}$ to antiBARMM political actors and inter-ethnic/clan rivals ${ }^{19}$-will look to exploit the politics of dashed expectations in the population. Violent extremists, especially those aligned with the Islamic State, ${ }^{20}$ have an ominous presence across the BARMM ${ }^{21}$ not simply because of the direct threat that they pose to lives, livelihoods, and stability but for their potential to exploit the fractures and missteps of a complex and fragile peace process.

History suggests that such fears are well founded. For over fifty years new and often more militant violent groups have emerged in the wake of failed peace efforts. If the Bangsamoro government cannot deliver the socio-economic, education, security, and health benefits expected of the peace dividend, then the pool of disenchanted people that may support peace spoilers will inevitably increase. During interviews, locals frequently spoke of the way recruiters had stigmatized involvement in the peace process, berated participants for the shame of "passivity," and stoked fears about counterterrorism efforts contrasted with the supposed honor and dignity of continuing centuries of armed struggle and heralding the promises of redemption that come through war. ${ }^{22}$ In summary, disengagement and reintegration activities will be critical to the success of the peace process both as a formal component of its normalization track ${ }^{23}$ and as an ongoing (if largely ad hoc) push to weaken the membership and support base of insurgent groups.

\section{Multidimensional \& multidirectional}

The brutal conflicts, socio-political unrest, and socio-economic hardships that have characterized much of Mindanao's history has resulted in a plethora of different sources of stigma, shame, and fear at play in this complicated milieu. Given that these are largely social emotions (i.e. manifestations of social constructs experienced relationally to other people and/or social norms), locals often

Report 10-26-2020.pdf. Similar findings emerged from the Lanao del Sur Youth Survey: Peace, Trust, and the Future of the $B A R M M$, administered by the author with local colleagues, involving 414 participants from across Lanao del Sur (2019-20). For example, when asked to respond to the statement that "The establishment of the BARMM and the success of the peace process will fix all or most of the problems in Mindanao," almost two-thirds of respondents either somewhat or strongly agreed compared to $20 \%$ who either somewhat or strongly disagreed.

18 Luke Lischin, "Surviving or thriving? COVID-19 and violent non-state actors in the Southern Philippines," New Mandala, September 9, 2020, https://www.newmandala.org/surviving-or-thriving-covid-19-and-violent-non-state-actors-in-the-southernphilippines/.

19 International Crisis Group, "Clan Politics and the Future of the Bangsamoro Peace Deal," April 14, 2020, https://www. crisisgroup.org/asia/south-east-asia/philippines/clan-politics-and-future-bangsamoro-peace-deal; International Crisis Group, "Southern Philippines: Tackling Clan Politics in the Bangsamoro," April 14, 2020, https://www.crisisgroup.org/asia/ south-east-asia/philippines/306-southern-philippines-tackling-clan-politics-bangsamoro.

20 For detailed analysis of pro-Islamic State groups in Mindanao, see: Joseph Franco, Unpacking violent extremism: Dynamics in the Philippines (Washington, D.C.: RESOLVE Network, 2020), https://doi.org/10.37805/pn2020.2.sea; Amira Jadoon, Nakissa Jahanbani, and Charmaine Willis, "Rising in the East: The evolution of the Islamic State in the Philippines," Combating Terrorism Center At West Point, December 2020, https://ctc.usma.edu/wp-content/uploads/2020/12/Rising-in-the-East-Report-2. pdf.

21 "The BARMM map," Republic of the Philippines, Bangsamoro Autonomous Region in Muslim Mindanao, https://bangsamoro. gov.ph/about-us/barmm-map/.

22 Author interviews in Marawi (2019), Cotabato (2019, 2020), and Zamboanga (2018).

23 For more see: Office of the Presidential Adviser on the Peace Process, "Full implementation of the MILF Normalization process underway," March 8, 2019, https://peace.gov.ph/2019/03/full-implementation-of-the-milf-normalization-process-underway/. 
expressed how a mix of tribal, gender, religious, and other identity roles (e.g. within the family) attached stigma and shame to certain beliefs and behaviors, while often simultaneously attaching honor, redemption, and empowerment to others. While the push and pull of these forces is felt by almost all people to varying degrees, it is particularly acute for young people who often spoke of how traditional roles intimately attached to gender, family, tribe, clan, and religious identities clashed with their professional, social, educational, and personal aspirations. ${ }^{24}$ It is during times of crisis that the impact of the expectations and tensions that emerge from these identities and its implications for social relationships are significantly amplified.

For instance, during times of conflict, broader kinship and ethno-tribal relationships can act as an informal surge capacity compelling people to mobilize in support of a particular side. The stigma and shame of not supporting the family, clan, or tribe during a conflict, not to mention the fear of reprisals, can act as an important driver of mobilization to violence, especially when coupled with promises of honor, redemption, and empowerment on the other side. Within violent extremist groups, engagement in beliefs and practices that are stigmatized by the broader population create a cycle of antagonistic forces that can trap members into cycles of violence difficult to escape.

The Abu Sayyaf Group (ASG) emerges as a pertinent example of the multidimensional (i.e. having different sources) and multidirectional (i.e. pushing and pulling the individual or group in different ways) nature of how stigma, shame, and fear can lock members into violent extremism. During interviews with former members and associates of ASG factions, ${ }^{25}$ it emerged how their adherence to a fringe interpretation of Islam, dislocation from traditional kinship ties (e.g. family), engagement in violence and other crimes against their own communities, and their use of shabu (methamphetamine) ${ }^{26}$ had created a web of interconnected stigmas, shames, and fears that acted as obstacles to disengagement and reintegration. ${ }^{27}$ Meanwhile, within the ASG, adhering to its ideology and engaging in violence, crime, and drug use was framed as honorable, redeeming, and empowering, helping to unify the ranks and drive a wedge between its members and the broader community. According to interviewees, ASG members who were considering defecting but ultimately decided to stay did so because the perceived obstacles for leaving were too great. ${ }^{28}$ For many, a physical addiction to shabu amidst a national war on drugs and a history of violence against the communities they were hoping to return to drove fears and shame that proved insurmountable.

24 Author interviews in Marawi (2018, 2019), Cotabato (2018, 2019), Zamboanga $(2018,2019)$, and Lanao del Sur Youth Survey results.

25 Author interviews in Zamboanga (2018).

26 Drug use in ASG ranks is well-known, anecdotally it is believed that drug addiction is rife amongst its members, and locals often derisively refer to the group as "Abu Shabu."

27 Rob Attwell, "Criminals With a Cause: The Crime-Terror Nexus in the Southern Philippines," The Diplomat, April 11, 2017, https://thediplomat.com/2017/04/criminals-with-a-cause-the-crime-terror-nexus-in-the-southern-philippines/; World Bulletin, "Philippines: Abu Sayyaf uses drugs for recruits, funds: military says findings show militant group involved in illegal drugs trade in troubled south, members on meth during combat," September 29, 2016, https://www.worldbulletin.net/asiapacific/philippines-abu-sayyaf-uses-drugs-for-recruits-funds-h177927.html; Jamela Alindogan. "Inside Abu Sayyaf: Blood, drugs and conspiracies," Al Jazeera, July 24, 2016, https://www.aliazeera.com/news/2016/07/abu-sayyaf-blood-drugs-conspiracies-160724090604857.html.

Author interviews in Zamboanga (2018). 


\section{Propelling the peace process}

The 2017 Marawi siege is a crucial event in the evolution of peace efforts in Mindanao. During interviews with locals who lived through the crisis, many saw the siege as an attempt by the proIslamic State group, described by locals as "the Maute-ISIS," to demonstrate that there is honor, redemption, and empowerment in violent struggle as an alternative to the stigma, shame, and fear of pursuing peace with the Moros' enemies. ${ }^{29}$ At the time of the siege, the peace process was hanging precariously in the balance after the 2015 firefight in Mamasapano, ${ }^{30}$ which killed dozens of police officers, threatening to undermine the progress made with the 2014 comprehensive agreement on Bangsamoro. ${ }^{31}$ The Marawi siege arguably strengthened the resolve of the Philippines government and the Moro Islamic Liberation Front to ensure that the peace process succeeded.

The approaches used to support the transition of former Moro Islamic Liberation Front fighters as part of the formal peace process will need to be strategically and programmatically different from government and civil society efforts to disengage and reintegrate members of groups outside of the peace process. The ongoing decommissioning of combatants and weapons from the Moro Islamic Liberation Front's Bangsamoro Islamic Armed Forces (BIAF), as part of the normalization track of the peace process, provides former combatants with a 100,000 Philippines pesos (approximately $\$ 2,080$ ) cash grant and access to assistance packages to support livelihood, scholarships, housing, and healthcare worth up to 1 million pesos (approximately $\$ 20,800$ ). ${ }^{32}$ So far, around 12,000 combatants have been decommissioned of a total of 40,000 to be decommissioned from the BIAF's general forces. ${ }^{33}$ Chief Minister Murad Ebrahim indicated that not all of those who had been decommissioned received the full support package, which had, in turn, resulted in many of those awaiting decommissioning expressing apprehensions about the process. ${ }^{34}$

For many former combatants, decommissioning is a time of acute uncertainty. Successful disengagement and reintegration require psychological, social, and practical (e.g. livelihood, security) support efforts to, amongst other aims, alleviate fears of what an "unarmed" future may mean, especially as spoilers look to stigmatize and shame those who choose peace. It will be vital that the promises that were made to those combatants scheduled for decommissioning are kept

29 See for example: Aaron Y. Zelin, “New video message from the Islamic State: 'Inside the Caliphate \#3,'” Jihadology, August 20, 2017, https://jihadology.net/2017/08/20/new-video-message-from-the-islamic-state-inside-the-caliphate-3/; Aaron Y. Zelin, “New release of the Islamic State's magazine: 'Rome \#10,'”Jihadology, June 7, 2017, https://jihadology.net/2017/06/07/ new-release-of-the-islamic-states-magazine-rome-10/.

30 Rappler, "Timeline: Mamasapano clash," February 7, 2015, https://www.rappler.com/nation/timeline-mamasapano-clash.

31 https://peacemaker.un.org/sites/peacemaker.un.org/files/PH 140327 ComprehensiveAgreementBangsamoro.pdf.

32 Interview with Chief Minister Murad Ebrahim by Christian Esguerra in Facts First with Christian Esguerra, "Episode 5: Pressure on the Bangsamoro," November 13, 2020, https://podcasts.apple.com/ph/podcast/facts-first/id1535361295?i=1000498432200.

33 Pia Ranada, "Checklist: What Bangsamoro gov't has accomplished so far," Rappler, January 21, 2021, https://www.rappler. com/newsbreak/iq/checklist-bangsamoro-government-accomplishments; Mindanao People's Caucus, Main Report: Rapid midterm review of the Bangsamoro transition period, October 2020, 47-54. https://iag.org.ph/images/pdf/Part II - Main REPORT October 262020.pdf.

34 Interview with Chief Minister Murad Ebrahim by Christian Esguerra in Facts First with Christian Esguerra, "Episode 5: Pressure on the Bangsamoro," November 13, 2020, https://podcasts.apple.com/ph/podcast/facts-first/id1535361295?i=1000498432200. 
as a minimum for ensuring sustainable disengagement and reintegration results. ${ }^{35}$ Failures and missteps in the normalization track risks disillusioning thousands of combatants and rendering them susceptible to the narratives of peace spoilers.

\section{Recommendations}

The following recommendations are built on the three key principles of outcompete, persuade, and support, offering a broad (though incomplete) framework for shaping disengagement and reintegration activities in Mindanao:

Capacity-building programs supporting peace efforts in Mindanao should include modules that provide multisector participants with an understanding of the psychosocial and strategic dynamics of stigma, shame, and fear together with a toolkit of strategic principles to inform program development.

Peacebuilding lexicon and practice tends to be the preferred approach of government and civil society actors in Mindanao. Capacity-building efforts should be grounded in peacebuilding approaches to build on extant local knowledge and experiences to expedite and maximize learning impact results. Trainings must focus on providing basic frameworks of understanding and practitioner toolkits that offer guiding principles for program design that are methodical, evidence-based, and persuasion-oriented. It is then up to the participants to selectively adopt and adapt what they have learned to develop initiatives or improve existing efforts, nuanced for local requirements. Additionally, capacity-building programs must also act as vehicles for shaping the individual mentality and the team culture of participants in a way that not only maximizes learning impact, retention, and application outcomes, but helps to ensure the efficacy and sustainability of local initiatives. ${ }^{36}$

Identifying and mapping prevailing pathways for continued engagement and potential re-engagement with violent groups is crucial for developing methodical, evidence-based, and persuasion-oriented approaches to disengagement and reintegration programming.

These "mapping" activities need to identify potential pathways and vulnerabilities that may emerge across individual, social, and structural levels. Identifying trends in how and why local people support violent groups is vital for nuancing disengagement and reintegration program design. For instance, at the most basic level, it is important to distinguish between the formal members of armed groups and "accidental guerrillas," ${ }^{37}$ i.e. people outside of the core group who may opportunistically support the armed group for a variety of reasons that often have little to do with ideological commitment. In conversations with government, military, and civil society representatives present during the Marawi siege, many indicated that the number of fighters

35 Gerg Cahiles, "Lacson: Bangsamoro 'normalization' projects must be funded regularly," CNN Philippines, September 22, 2020, https://www.cnnphilippines.com/news/2020/9/22/OPAPP-budget-Bangsamoro.html.

36 The author has led the design and implementation of several such programs across Mindanao, particularly in Lanao del Sur and Maguindanao.

37 For more, see David Kilcullen, The Accidental Guerrilla: Fighting small wars in the midst of a big one (London: Hurst \& Company, 2009). 
who participated in the siege were inflated, especially during the initial weeks, by opportunistic "accidental guerrillas" who accessed the city via Lake Lanao motivated by the prospect of excitement and acquiring "war loot." Identifying such nuances can have important implications for disengagement and reintegration efforts. After all, those who supported violent groups driven by more fleeting motivations such as excitement or monetary gain will likely require different disengagement and reintegration opportunities and incentives to those who were members due to a deep ideological commitment or kinship ties.

Feelings of stigma, shame, and fear can sometimes be more acute for those who opportunistically supported violent groups than those with a deeper commitment to the cause. Civil society representatives from Marawi highlighted cases where individuals who fleetingly participated in the 2017 siege were ostracized, fearful of repercussions, and ashamed of their actions, which had, in turn, made them less likely to participate in rehabilitation programs. ${ }^{38}$ For some who had moved on with their lives and whose involvement was not broadly known, participation in a program was understandably seen as a greater risk than benefit. For others, however, the process of returning to the community has been slow, requiring personalized strategies designed to, as much as possible, render pathways back to violence inviable before looking to methodically address individual, social, and structural obstacles towards reintegration.

Pathway and vulnerability mapping is programmatically important because it demands practitioners to engage in regular, critical, and methodical assessments of individual, social, and structural factors at play in their local communities. Over time, regular assessments may collectively provide a nuanced picture of changes and trends that can be used to improve understanding and practice. After all, the variety of potential motivations and pathways for participation in violence will shape the extent to which stigma, shame and fear emerge as obstacles or opportunities for disengagement and reintegration. Mapping can also help inform more preventative measures such as the provision of psychosocial support for those who have experienced traumas.

Complex and compounding cycles of stigma, shame, and fear may impact not only the individual but their broader kinship network, which can be harnessed towards good or ill. Practitioners must outcompete violent extremists in persuading their target audiences by leveraging many of the same psychosocial forces-just in different ways.

One of the most interesting and inspiring examples of negative feelings motivating positive actions has been the extraordinary efforts and achievements of women as civil society advocates in Marawi. During workshops, many women from Lanao del Sur (particularly Maranao women from Marawi) indicated that their involvement in civil society efforts was largely driven by feelings of unease, but sometimes even shame and guilt, that they had not done enough to prevent people from their communities from joining pro-Islamic State and other violent extremist groups. Many suggested that this sentiment was heightened by learning of how the activities of the Maute matriarch and other women had had a seemingly disproportionate impact on Islamic State recruitment and mobilization efforts leading to and during the Marawi siege. ${ }^{39}$

38 Author interviews in Marawi (2018, 2019, 2020).

39 Ana P. Santos and Nikko Dizon, "Women of the Eastern Caliphate Part 2: By Blood and Marriage," Pulitzer Center, January 2, 2020, https://pulitzercenter.org/reporting/women-eastern-caliphate-part-2-blood-and-marriage-0. 
This example also underscores the importance of genuinely empowering local women to be directly involved in program development and implementation. ${ }^{40}$ Women have often played a central role in grassroots efforts across Mindanao to help transform the pain and guilt associated with involvement in violent extremist groups into a motivational driver to leave. After all, stigma, shame, and fear can be drivers towards disengagement and reintegration, especially if opportunities to achieve honor, redemption, and empowerment are on offer via not only prosocial and reconciliation-focused activities but practical opportunities for vocational training and employment. Trusted, local grassroots networks that have been trained to map vulnerabilities and pathways, apply a methodical and persuasively oriented approach to programming, and, ideally, have the kinship networks into these groups can facilitate disengagement and reintegration.

\section{Disengagement and reintegration activities conducted as part of a formal peace process must reduce barriers to and maximize incentives for participation.}

The Bangsamoro peace process is a complicated political, legal, and bureaucratic process that is reliant on the goodwill and commitment of its participants. This is especially pertinent when considering the normalization track of the peace agreement. Alleviating uncertainty for former combatants through the provision of support packages and avoiding say-do gaps by ensuring that messaging is reflected in actions (and vice versa) are practically and symbolically important for demonstrating the credibility of the peace process. Maximizing incentives and reducing barriers within this context are vital to achieve decommissioning objectives and sustainable peace. Such efforts, however, do not occur in a vacuum, and peace spoilers, especially pro-Islamic State groups and other anti-BARMM actors, will be keen to exploit broken promises and the politics of dashed expectations to attract trained, experienced, and potentially armed fighters disillusioned by another faltering peace agreement. Maintaining pressure on spoiler groups who may seek to exploit missteps in the peace process will be important, including persuading their members to disengage and reintegrate.

Disengagement and reintegration programs catering to groups outside of the formal peace process will need different approaches. While it may be more appropriate to strategically increase the cost of redemption for members of violent extremist groups, especially those that attacked local communities (e.g. pro-Islamic state groups), to achieve greater support and investment from the broader community, this requires careful balancing in program design and implementation. In interviews with locals from Marawi, a sense of disappointment and resentment (even anger) was often expressed regarding the opportunities afforded to defectors from pro-Islamic State groups. A common refrain was that "defectors are treated better than IDPs." ${ }^{41}$ Increasing the commitments required of participants in disengagement and reintegration initiatives is important for not only building greater and more active community support but increasing the perceived value associated with participation for defectors themselves. To outcompete violent extremists, programs may require participants to take part in a mix of reconciliation, impact awareness, and community service activities, while ensuring that their commitment is symbolically and practically incentivized yet balanced with other considerations such as support for victims.

40 For an overview of key guiding principles for informing the design and implementation of gender-specific initiatives in Mindanao, see: Kiriloi M. Ingram, "Revisiting Marawi: Women and the Struggle Against the Islamic State in the Philippines," Lawfare, August 4, 2019, https://www.lawfareblog.com/revisiting-marawi-women-and-struggle-against-islamic-state-philippines.

41 Author interviews in Marawi and Cotabato in 2019 and 2020. 
Amnesty windows may help facilitate multisector disengagement and reintegration efforts. Coordinating public messaging and grassroots civil society activities is crucial in Mindanao and across the BARMM, where some of the most vulnerable communities to the recruitment activities of peace spoilers are also amongst the most isolated. For instance, a public messaging campaign targeting key audiences leading to, during, and after an amnesty window should be synchronized with actions that demonstrate that disengagement and reintegration opportunities are genuine. When civil society are aware of upcoming amnesty windows, they can then reach out to members and their kinship networks to coordinate and complement public messaging. While amnesty windows should not be the only occasion for encouraging defections, they may be pertinent for the southern Philippines where military operations remain the primary counterterrorism tool.

\section{Conclusion}

While there are immense challenges ahead for the people of Mindanao, there are tangible reasons to be hopeful, even optimistic, for the future. Despite its challenges, the BARMM government has performed admirably since 2019 and continues to achieve important milestones amidst the COVID-19 pandemic. Nationally, while the coronavirus pandemic and response has slowed the rollout of the Philippines government's National Action Plan for Preventing and Countering Violent Extremism, there is an opportunity for Manila and Cotabato to synchronize on preventative efforts at a crucial time in Mindanao's history. Perhaps most promising of all is Mindanao's active civil society sector that have tirelessly and passionately worked against the odds, at great risk, and with limited support to build stronger and more resilient communities against violent extremist threats.

This policy note offers a basic roadmap and policy framework designed to understand and harness the psychosocial and strategic dynamics of stigma, shame, and fear-factors with significant implications for both engagement in violence and post-conflict reintegration effortsto outcompete violent extremists seeking to spoil the most promising opportunity for peace in decades. 


\section{Suggested further readings}

\section{On the history of peace processes in Mindanao}

Bacani, Benedicto R. "The Mindanao Peace Talks." United States Institute of Peace, Special Report, January 2005. https://www.usip.org/sites/default/files/sr131.pdf.

Martin, Eugene. "On the Issues: Philippines," United States Institute of Peace, September 18, 2008. https:// www.usip.org/publications/2008/09/issues-philippines.

Rood, Steven. The Philippines. New York: Oxford University Press, 2019. https://global.oup.com/academic/ product/the-philippines-9780190920609?cc=us\&lang=en\&.

\section{On the Bangsamoro Autonomous Region of Muslim Mindanao}

Abuza, Zachary, and Luke Lischin. "The Challenges Facing the Phlippines' Bangsamoro Autonomous Region at One Year." United States Institute of Peace, Special Report, June 10, 2020. https://www.usip.org/index. php/publications/2020/06/challenges-facing-philippines-bangsamoro-autonomous-region-one-year.

Mindanao People's Caucus. Main Report: Rapid Midterm Review of the Bangsamoro Transition Period. October 2020. https://iag.org.ph/images/pdf/Part II - Main REPORT October 262020.pdf.

Ranada, Pia. "Checklist: What Bangsamoro gov't has accomplished so far." Rappler, January 21, 2021. https://www.rappler.com/newsbreak/iq/checklist-bangsamoro-government-accomplishments.

\section{On 'peace spoilers' in Mindanao}

Franco, Joseph. Unpacking Violent Extremism: Dynamics in the Philippines. Washington, D.C.: RESOLVE Network, 2020. https://doi.org/10.37805/pn2020.2.sea.

Ingram, Kiriloi M. "Revisiting Marawi: Women and the Struggle Against the Islamic State in the Philippines." Lawfare, August 4, 2019. https://www.lawfareblog.com/ revisiting-marawi-women-and-struggle-against-islamic-state-philippines.

Jadoon, Amira, Nakissa Jahanbani, and Charmaine Willis. "Rising in the East: The evolution of the Islamic State in the Philippines." Combating Terrorism Center At West Point, December 2020. https://ctc.usma. edu/wp-content/uploads/2020/12/Rising-in-the-East-Report-2.pdf.

On applying the linkage approach to inform propaganda analysis and PCVE programs

Berger, JM. Extremism. Cambridge: MIT Press, 2018. https://www.penguin.com.au/books/ extremism-9780262535878.

EISayed, Lilah, Sara Zeiger, Muna Chung, and Farangiz Atamuradova. Planting the Seeds of the Poisonous Tree: Establishing a system of meaning through ISIS education. Washington, D.C.: George Washington University Program on Extremism, 2021. https://isisfiles.gwu.edu/ catalog?f\%5Bmember of collection ids ssim\%5D\%5B\%5D=z316q1572.

Ingram, Haroro J. "The Strategic Logic of Islamic State's Full-spectrum Propaganda." In ISIS Propaganda: A FullSpectrum Extremist Message edited by Stephane J. Baele, Katharine A. Boyd, and Travis G. Coan, 20-49. New York: Oxford University Press, 2020. https://doi.org/10.1093/oso/9780190932459.003.0002. 
Reed, Alastair, and Jennifer Dowling. "The role of historical narratives in extremist propaganda." Defence Strategic Communications, Volume 4 (Spring 2018): 79-104. https://www.stratcomcoe.org/ alastair-reed-jennifer-dowling-role-historical-narratives-extremist-propaganda.

Whittaker, Joe, and Lilah Elsayed. "Linkages as a lens: An exploration of strategic communications in P/ CVE," Journal of Deradicalization 20 (2019). https://journals.sfu.ca/jd/index.php/jd/article/view/243.

\section{On peacebuilding approaches to disengagement and reintegration}

Bosley, Chris. "Violent extremist disengagement and reconciliation: A peacebuilding approach." United States Institute of Peace, 2020. https://www.usip.org/publications/2020/07/ violent-extremist-disengagement-and-reconciliation-peacebuilding-approach.

Steadman, Leanne Erdberg. "Disengagement and Reconciliation in Conflict-Affected Settings." United States Institute of Peace, 2020. https://www.usip.org/publications/2020/08/ disengagement-and-reconciliation-conflict-affected-settings.

\section{Bibliography}

Abuza, Zachary, and Luke Lischin. "The Challenges Facing the Phlippines' Bangsamoro Autonomous Region at One Year." United States Institute of Peace, Special Report, June 10, 2020. https://www.usip.org/index.php/ publications/2020/06/challenges-facing-philippines-bangsamoro-autonomous-region-one-year.

Alindogan, Jamela. "Inside Abu Sayyaf: Blood, drugs and conspiracies." Al Jazeera, July 24, 2016. https://www. aljazeera.com/news/2016/07/abu-savyaf-blood-drugs-conspiracies-160724090604857.html.

Altier, Mary Beth, Christian N. Thoroughgood, and John G. Horgan. "Turning away from terrorism: Lessons from psychology, sociology, and criminology." Journal of Peace Research 51, no. 5 (2014): 647-661.

Altier, Mary Beth, Emma Leonard Boyle, Neil D. Shortland, and John G. Horgan. "Why they leave: An analysis of terrorist disengagement events from eighty-seven autobiographical accounts." Security Studies 26, no. 2 (2017): 305-332.

Attwell, Rob. "Criminals with a Cause: The Crime-Terror Nexus in the Southern Philippines." The Diplomat, April 11, 2017. https://thediplomat.com/2017/04/criminals-with-a-cause-the-crime-terror-nexus-in-the-southern-philippines/.

Berger, JM. Extremism. Cambridge: MIT Press, 2018.

Bosley, Chris. "Violent extremist disengagement and reconciliation: A peacebuilding approach." United States Institute of Peace, 2020. https://www.usip.org/publications/2020/07/ violent-extremist-disengagement-and-reconciliation-peacebuilding-approach.

Brown, Brene. "Shame resilience theory: A grounded theory study on women and shame." Families in Society 87 (2006). https://journals.sagepub.com/doi/10.1606/1044-3894.3483.

Cahiles, Gerg. "Lacson: Bangsamoro 'normalization' projects must be funded regularly." CNN Philippines, September 22, 2020. https://www.cnnphilippines.com/news/2020/9/22/OPAPP-budget-Bangsamoro.html.

Doosje, Bertjan, Annemarie Loseman, and Kees van den Bos. "Determinants of Radicalization of Islamic Youth in the Netherlands: Personal Uncertainty, Perceived Injustice, and Perceived Group Threat." Journal of Social Issues 69, no. 3 (2013): 586-604. 
Engelbrecht, Georgi. "Covid-19 shakes South Philippine peace deal." Asia Times, December 4, 2020. https://asiatimes. com/2020/12/covid-19-shakes-south-philippine-peace-deal/.

Esguerra, Christian. Facts First with Christian Esguerra, "Episode 5: Pressure on the Bangsamoro." November 13, 2020. https://podcasts.apple.com/ph/podcast/facts-first/id1535361295?i=1000498432200.

Franco, Joseph. Unpacking Violent Extremism: Dynamics in the Philippines. Washington, D.C.: RESOLVE Network, 2020. https://doi.org/10.37805/pn2020.2.sea.

Hareli, Shlomo, and Brian Parkinson. "What's social about social emotions?." Journal for the Theory of Social Behaviour 38, no. 2 (2008): 131-156.

Hogg, Michael A., and Janice Adelman. "Uncertainty-Identity Theory: Extreme Groups, Radical Behavior, and Authoritarian Leadership." Journal of Social Issues 69, no. 3 (2013): 436-454.

Hogg, Michael A., Arie Kruglanski, and Kees van den Bos. "Uncertainty and the Roots of Extremism." Journal of Social Issues 69, no. 3 (2013): 407-418. https://doi.org/10.1111/josi.12021.

Ingram, Haroro J. Deciphering the Siren Call of Militant Islamist Propaganda. International Centre for Counter-Terrorism - The Hague, September 2016. https://icct.nl/wp-content/uploads/2016/09/ICCT-Ingram-Deciphering-theSiren-Call-of-Militant-Islamist-Propaganda-September2016.pdf.

Ingram, Haroro J. "The Strategic Logic of Islamic State's Full-spectrum Propaganda." In ISIS Propaganda: A Full-Spectrum Extremist Message edited by Stephane J. Baele, Katharine A. Boyd, and Travis G. Coan, 20-49. New York: Oxford University Press, 2020. https://doi.org/10.1093/oso/9780190932459.003.0002.

Ingram, Kiriloi M. IS's Appeal to Western Women: Policy Implications. International Centre for Counter-Terrorism - The Hague, October 2017. https://www.jstor.org/stable/resrep17481?seq=1\#metadata_info_tab_contents

Ingram, KiriloiM. "Revisiting Marawi:WomenandtheStruggleAgainstthelslamicStateinthePhilippines." Lawfare, August 4, 2019. https://www.lawfareblog.com/revisiting-marawi-women-and-struggle-against-islamic-state-philippines.

International Crisis Group. "Clan Politics and the Future of the Bangsamoro Peace Deal." April 14, 2020. https://www. crisisgroup.org/asia/south-east-asia/philippines/clan-politics-and-future-bangsamoro-peace-deal.

International Crisis Group. "Southern Philippines: Tackling Clan Politics in the Bangsamoro." April 14, 2020. https://www. crisisgroup.org/asia/south-east-asia/philippines/306-southern-philippines-tackling-clan-politics-bangsamoro.

Jadoon, Amira, Nakissa Jahanbani, and Charmaine Willis. "Rising in the East: The evolution of the Islamic State in the Philippines." Combating Terrorism Center At West Point, December 2020. https://ctc.usma.edu/wp-content/ uploads/2020/12/Rising-in-the-East-Report-2.pdf.

Khalil, James. "Insurgent-populace relations in Nepal: An analysis of attitudinal and behavioural support." Small War and Insurgencies 23, no. 2 (2012): 221-244.

Kilcullen, David. The Accidental Guerrilla: Fighting small wars in the midst of a big one. London: Hurst \& Company, 2009.

Lewis, Helen Block. Shame: The "sleeper" in psychopathology. Hillsdale: Erlbaum, 1987.

Lischin, Luke. "Surviving or thriving? COVID-19 and violent non-state actors in the Southern Philippines." New Mandala, September 9, 2020. https://www.newmandala.org/surviving-or-thriving-covid-19-and-violent-non-stateactors-in-the-southern-philippines/. 
Major, Brenda, and Laurie T. O’Brien. "The Social Psychology of Stigma." Annual Review of Psychology 56 (February 2005): 393-421.

Mindanao People's Caucus. Rapid midterm review of the Bangsamoro transition period. October 2020. https://iag. org.ph/images/pdf/Part I Final Report 10-26-2020.pdf.

Mindanao People's Caucus. Main Report: Rapid midterm review of the Bangsamoro transition period. October 2020, 47-54. https://iag.org.ph/images/pdf/Part II - Main REPORT October 262020.pdf.

Office of the Presidential Adviser on the Peace Process. "Full implementation of the MILF Normalization process underway." March 8, 2019. https://peace.gov.ph/2019/03/full-implementation-of-the-milf-normalization-process-underway/.

Rappler. "Timeline: Mamasapano clash." February 7, 2015. https://www.rappler.com/nation/ timeline-mamasapano-clash.

Ranada, Pia. "Checklist: What Bangsamoro gov't has accomplished so far." Rappler, January 21, 2021. https://www. rappler.com/newsbreak/iq/checklist-bangsamoro-government-accomplishments.

Reed, Alastair, and Jennifer Dowling. "The role of historical narratives in extremist propaganda." Defence Strategic Communications, Volume 4 (Spring 2018): 79-104. https://www.stratcomcoe.org/ alastair-reed-jennifer-dowling-role-historical-narratives-extremist-propaganda.

Rood, Steven. The Philippines. New York: Oxford University Press, 2019.

Santos, Ana P., and Nikko Dizon. "Women of the Eastern Caliphate Part 2: By Blood and Marriage." Pulitzer Center, January 2, 2020. https://pulitzercenter.org/reporting/women-eastern-caliphate-part-2-blood-and-marriage-0.

Schiavo-Campo, Salvatore, and Mary Judd. "'The Mindanao conflict in the Philippines: Roots, costs, and potential peace dividend." World Bank, Social Development Paper series, Conflict Prevention \& Reconstruction, 2005. http://documents.worldbank.org/curated/en/701961468776746799/pdf/31822.pdf.

Steadman, Leanne Erdberg. "Disengagement and Reconciliation in Conflict-Affected Settings." United States Institute of Peace, 2020. https://www.usip.org/publications/2020/08/ disengagement-and-reconciliation-conflict-affected-settings.

Tomacruz, Sofia. "Now that Bangsamoro law is ratified, what comes next?." Rappler, January 31, 2019. https://www. rappler.com/newsbreak/iq/221995-things-to-know-transition-bangsamoroorganic-law.

Whittaker, Joe, and Lilah Elsayed. "Linkages as a lens: An exploration of strategic communications in P/CVE," Journal of Deradicalization 20 (2019). https://journals.sfu.ca/id/index.php/id/article/view/243.

World Bank Group. Mind, Society, and Behavior, World Development Report 2015.

Yu, Rongjun. "Stress potentiates decision biases: A stress induced deliberation-to-intuition (SIDI) model." Neurobiology of Stress 3 (2016): 83-95.

Zelin, Aaron Y. "New video message from the Islamic State: 'Inside the Caliphate \#3."' Jihadology, August 20, 2017. https://jihadology.net/2017/08/20/new-video-message-from-the-islamic-state-inside-the-caliphate-3/.

Zelin, Aaron Y. “New release of the Islamic State's magazine: 'Rome \#10.'J Jihadology, June 7, 2017. https://jihadology. net/2017/06/07/new-release-of-the-islamic-states-magazine-rome-10/. 


\section{About the Note}

Author: Haroro J. Ingram

HaroroJ. Ingram is a senior research fellow with the Program on Extremism at George Washington University (Washington D.C), a member of the Resolve Network's Research Advisory Council (Washington D.C.), and a fellow with the Institute for Peace and Development in Mindanao at Mindanao State University (Marawi).

The views expressed in this publication are those of the authors. They do not necessarily reflect the views of the RESOLVE Network, the U.S. Institute of Peace, or any entity of the U.S. government.

\section{RESOLVE NETWORK}

better research.informed practice.improved policy on violent extremism.

www.resolvenet.org

y 9 in 